\title{
The Effect of Company Sizes and Net Working Capital on Cash Holding With Profitability as Intervening Variables in Food and Beverage Sub Sector Companies Registered in Indonesia Stock Exchange
}

\author{
Murtiadi Awaluddin', Elis' ${ }^{2}$, Sri Prilmayanti Awaluddin'3, \\ Rulyanti Susi Wardhani ${ }^{4}$, Syarif Syahrir Malle5 \\ 1,2,5Universitas Islam Negeri Alauddin Makassar \\ Jln. HM. Yasin Limpo, No.36, Romangpolong-Gowa, Sulawesi Selatan \\ 3 STIE Nobel Indonesia \\ Jln. Sultan Alauddin No.212, Mangasa, Kota Makassar, Sulawesi Selatan \\ 4Universitas Bangka Belitung, Kampus Terpadu UBB, Balunjuk, Kep. Bangka Belitung \\ E-mail: murtiadi.awaluddin@uin-alauddin.ac.id
}

\begin{abstract}
,
The COVID-19 pandemic that has hit the world including Indonesia since early 2020 has had The purpose of this study was to determine and analyze the influence of company size and net working capital towards holding cash with profitability as an intervening variable. This Research uses quantitative methods with 2013-2017 observation years. The research sample consisted of 15 food and beverage sub-sector companies listed on the Indonesia Stock Exchange, while the method used was purposive sampling. The analytical method used is multiple linear regression and path analysis. The results showed the size of the company had a negative and not significant effect on profitability, net working capital was positive and not significant on profitability. Company size, net working capital, and profitability have a positive and significant influence on cash holding. Profitability is not able to mediate the effect of company size on cash holding.But profitability is able to mediate the effect of net working capital on cash holding.
\end{abstract}

Keywords: Company Size, Net Working Capital, Profitability, Cash Holding

\section{INTRODUCTION}

One of the characteristics of a company is said to be good when a company has a good level of liquidity. Liquidity is the ability of a company to meet its short-term obligations that have matured (Riyanto,1998:25). One way to minimize the company's liquidity risk is to maintain a cash holding level. According to Gill and Shah (2012), Cash holding is cash contained in a company to be invested in physical assets and to be distributed to investors as dividends. Cash holding is used as a reserve for the company in carrying out its operational activities and to fulfill the company's financial obligations on time.

The size of the company's cash holding is influenced by several factors such as the size of the company, net working capital, and profitability. According to Suhartono (2016:122) profitability is the ability of companies to earn profits concerning sales, total assets, and own capital. If Profitabilitas companies higher then the level of cash holding companies also will be high, as profitability has close ties to the increased cash holding companies (Simanjuntak and Wahyudi, 2017). The research conducted by Hapsari (2015) states that profitability has a positive and significant effect on cash holding. However, research conducted by Jamil, et al (2016) shows different results, where profitability has a negative and not significant effect on cash holding. 
Factors other that may affect the cash holding is net working capital. Networking capital can determine the level of cash holding companies because cash is part of networking capital so that when cash increases, networking capital will also increase (Wiradharma, et al, 2017). The research conducted by Jinkar (2013) found that networking capital had a positive and significant effect on cash holding, while research conducted by Simanjuntak and Wahyudi (2017) stated that networking capital had a negative and significant effect on cash holding.

In addition to profitability and net working capital, company size can also affect the company's cash holding level. The greater the size of the company, the higher the profit generated by the company (Oktaviany, et al, 2019), if profits are high, the company can increase its cash holdings. Afif's research (2016) states that company size has a positive and significant effect on cash holding, while the research of Liestyasih and Wiagustini (2017) found that company size has a negative and significant effect on company cash holding.

The following is the data of average company size, working capital, profitability, and cash holding companies in the food and beverage sub-sector listed on the Stock Exchange in 2013-2017:

\begin{tabular}{|c|c|c|c|c|c|}
\hline \multicolumn{6}{|l|}{25} \\
\hline 20 & & & & & \\
\hline 15 & & & & & \\
\hline 10 & & & & & \\
\hline $5-$ & & & & & \\
\hline 0 & 2013 & 2014 & 2015 & 2016 & 2017 \\
\hline Ukuran Perusahaan & 14.56 & 14.68 & 14.78 & 14.89 & 15.01 \\
\hline Net Working Capital & 23.18 & 22.24 & 20.76 & 22.34 & 23.29 \\
\hline Profitabilitas & 11.4 & 8.55 & 7.62 & 9.3 & 7.81 \\
\hline Cash Holding & 13.45 & 12.41 & 13.15 & 14.93 & 16.58 \\
\hline
\end{tabular}

The picture above shows that in 2014 the size of the company increased by 14.68\% while cash holding decreased and in 2016 the size of the company and cash holding both increased. Furthermore, networking capital and profitability in 2014 decreased by $22.24 \%$ and $8.55 \%$, and this was followed by a decrease in cash holding, then in 2015 net working capital and profitability again declined but cash holding increased. This shows an inconsistent relationship between company size, net working capital, and profitability towards cash holding. whereas in theory when company size, net working capital and profitability increase, cash holding will also increase.

Based on the background description and the existence of a research gap from previous research, the following problem statements are made:

1. Does the size of the company affect profitability?

2. Does net working capital affect profitability?

3. Does profitability affect cash holding? 
4. Does company size affect cash holding?

5. $\quad$ Does net working capital affect cash holding?

6. Does company size affect cash holding through profitability?

7. $\quad$ Does net working capital affect cash holding through profitability?

\section{LITERATURE REVIEW}

1. Effect of company size on profitability

Company size is a big picture of the size of a company that is shown from the total assets owned by the company. Large size companies have large resources with large operational activities so that they are directly able to show that the company has a large potential in making a profit (Octaviani, et al, 2019). According to Ardiana and Chabachib (2018), company size has a positive and significant effect on profitability.

2. The effect of net working capital on profitability

Net working capital is current assets that can be used to finance company operational activities without disrupting company liquidity. Sufficient working capital is very important for the long-term survival of the company, in the absence of working capital the company's operational activities will Tegan GGU and this will have an impact on profitability as companies (Parmita, 2017). Also with adequate working capital, the company can operate economically and efficiently so that the company can obtain high profitability. Supriadi and Puspitasari (2011) stated that net working capital has a positive and significant effect on profitability.

\section{Effect of profitability on cash holding}

Profitability is the company's ability to make a profit. Profitability has a close relationship with increasing the company's cash holding (Simanjuntak and Wahyudi, 2017). Companies that have ting kat high profitability had a chance to make the profit he gets into retained earnings and may also add cash holdings company. Hapsari (2015) states that profitability has a positive and significant effect on cash holding.

\section{Effect of company size on cash holding}

The greater the size of the company, the greater the total assets owned by the company. The size of the company will affect the size of the operating cash flow obtained by the company. Companies with large sizes will automatically have a large operational cash flow (Rahmawati, 2013). Syafrizaliadhi and Arfianto (2014), stated that company size had a positive and significant effect on cash holding.

\section{The effect of net working capital on cash holding}

Cash is part of net working capital so that when cash increases, net working capital will also increase (Wiradharma, et al, 2017). In addition, in certain conditions current assets except cash cannot be a substitute for cash at any time for example in times of crisis, therefore corporate finance managers usually make cash reserves to maintain company liquidity 
6. The effect of company size on cash holding with profitability as an intervening variable

The size of the company can be interpreted as the size of a company that is measured by the number of assets it has. Large size companies have great potential to increase profitability (Octaviani, et al, 2019). Companies that have high levels of profitability have the opportunity to make the profits they get as additional cash holding. D ith so the larger the company, the greater the company's ability to result in profits that will impact the company's cash holdings increase.

7. Effect of net working capital to cash holdng with profitability as variab e l intervening

Networking capital is used to carry out company operational activities, so working capital can directly affect the profitability of the company. Profitability acquired companies that can become retained earnings and can also add cash holding companies. Companies prefer to use retained earnings to finance their operational activities rather than issuing relatively expensive equity (Silean and Prasetiono, 2017).

\section{Conceptual framework}

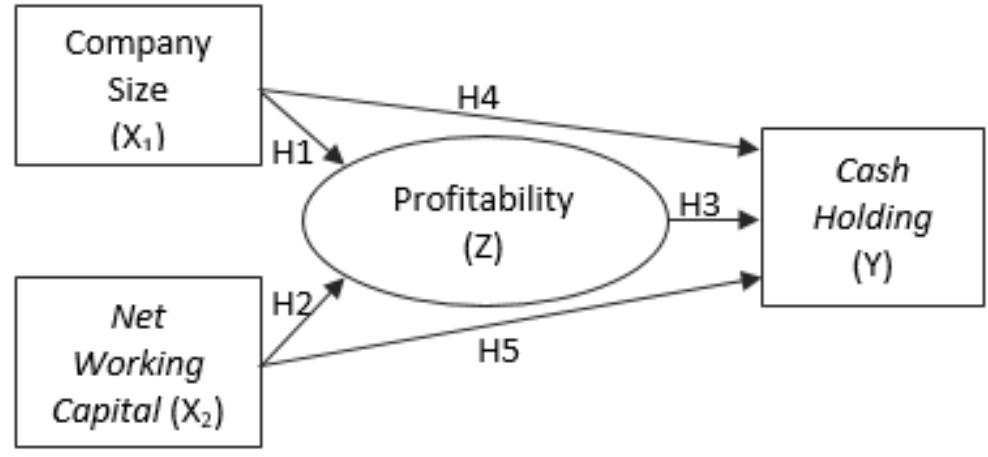

\section{Research Hypothesis}

$\mathrm{H}_{1}$ : Company size has a positive and significant effect on profitability

$\mathrm{H}_{2}$ : Net working capital has a positive and significant effect on profitability

$\mathrm{H}_{3}$ : Profitability has a positive and significant effect on cash holding

$\mathrm{H}_{4}$ : Company size has a positive and significant effect on cash holding.

$\mathrm{H}_{5}$ : Net working capital has a positive and significant effect on cash holding.

$\mathrm{H}_{6}$ : Company size has a positive and significant effect on cash holding through profitability..

$\mathrm{H}_{7}$ : Net working capital has a positive and significant effect on cash holding through profitability 


\section{METHODS}

The type of research used is quantitative research with causal associative research methods. The location of this study conducted in the Indonesia Stock Exchange (IDX) with data retrieval via the official website www.idx.co.id. The population in this study are food and beverage sub-sector companies listed on the Stock Exchange in the 2013-2017 study period. The determination of the sample in this study is to use purposive sampling to obtain a sample of 15 companies.

The data analysis technique used is the classical assumption consisting of tests of normality, multicollinearity, autocorrelation, and heteroscedasticity. Next is the Hypothesis test consisting of the coefficient of determination test, Simultaneous test, and Partial test. Then analyze A path to test the effect of intervening variables.

\section{DISCUSSION}

\section{Classic Assumptions Test}

The Classic Assumption Test used in this study is the normality test, multicollinearity test, autocorrelation test, and heteroskedasticity test. The test results show that the research data do not have a classic assumption deviation:

\section{Hypothesis testing}

Table 1. Hypothesis Test Model I

Coefficients a

\begin{tabular}{|c|c|c|c|c|c|}
\hline \multirow[t]{2}{*}{ Model } & \multicolumn{2}{|c|}{$\begin{array}{c}\text { Unstandardized } \\
\text { Coefficients }\end{array}$} & $\begin{array}{l}\text { Standardized } \\
\text { Coefficients }\end{array}$ & \multirow[t]{2}{*}{$\mathrm{T}$} & \multirow[t]{2}{*}{ Sig. } \\
\hline & $\mathrm{B}$ & Std. Error & Beta & & \\
\hline (Constant) & .216 & .127 & & 1,710 & .92 \\
\hline Company Size & -.009 & .009 & -.127 & $-1,090$ & 279 \\
\hline Net Working Capital & .083 & .060 & .162 & 1,390 & .169 \\
\hline
\end{tabular}

1. Effect of Company Size on Profitability

The coefficient value of the Enterprise Size variable (X1) is -0.009 and the probability value is 0.279 so it can be said that Company Size has a negative and not significant effect on profitability, so $\mathrm{H} 1$ is rejected.

2. The Effect of Net Working Capital on Profitability

The coefficient value of the Net Working Capital variable (X2) is 0.083 and the probability value is 0.169 , it can be said that Net Working Capital has a positive but not significant effect on profitability, so $\mathrm{H} 1$ is rejected. 
Table 2. Hypothesis Testing Model II

Coefficients a

\begin{tabular}{|l|r|r|r|r|r|}
\hline Model & \multicolumn{2}{|c|}{$\begin{array}{c}\text { Unstandardized } \\
\text { Coefficients }\end{array}$} & $\begin{array}{c}\text { Standardized } \\
\text { Coefficients }\end{array}$ & \multirow{2}{*}{ Sig. } & \\
\cline { 2 - 4 } & \multicolumn{1}{c|}{ B } & Std. Error & \multicolumn{1}{c|}{ Beta } & \\
\hline (Constant) & -.244 & .117 & & $-1,923$ & .058 \\
Company Size & .019 & .008 & .203 & 2.480 & .016 \\
Net Working Capital & .321 & .055 & .481 & 5847 & .000 \\
Profitability & .576 & .107 & .444 & 5,409 & .000 \\
\hline
\end{tabular}

a. Dependent Variable: Cash Holding

1. Effect of Profitability on Cash Holding

The coefficient value of the Profitability variable $(\mathrm{Z})$ is 0.576 and the probability value is 0,000 , so it can be said that Profitability has a positive and significant effect on Cash Holding, so that $\mathrm{H}_{3}$ is accepted.

\section{Effect of Company Size on Cash Holding}

The coefficient value of the Company Size variable (X1) is 0.019 and the probability value is 0.016 , so it can be said that Company Size has a positive and significant effect on Cash Holding, so $\mathrm{H}_{4}$ is accepted.

\section{The Effect of Net Working Capital on Cash Holding}

The coefficient value of the Net Working Capital variable (X2) is 0.321 and the probability value is 0.000 , it can be said that Net Working Capital has a positive and significant effect on Cash Holding, so that $\mathrm{H}_{5}$ is accepted.

\section{Path Path Analysis}

Path analysis is done by using a sobel test to prove the effect of Company Size and Net Working Capital on Cash Holding through Profitability. Sobel test results can be seen in the following table:

Table 3 Sobel Test Results

\begin{tabular}{lll}
\hline $\mathrm{X} 1 \rightarrow \mathrm{Z} \rightarrow \mathrm{Y}$ & T-count & T-table \\
$\mathrm{X} 2 \rightarrow \mathrm{Z} \rightarrow \mathrm{Y}$ & $-4,059$ & 1,667 \\
\hline
\end{tabular}

1. Effect of company size on cash holding through profitability

Based on the sobel test results, the calculated t-value of -4.059 while the t-table of 1.667. Thus, t-count <t-table means that profitability is not able to mediate the effect of company size on cash holding. Then H6 is rejected.

2. The Effect of Net Working Capital on Cash Holding through Profitability

Based on the sobel test results, the t-count value was 2.235 while the t-table was 1.667. Thus, t-> t-table means that profitability is able to mediate the influence of $\mathrm{Net}$ Working Capital on Cash Holding. Then $\mathrm{H} 7$ is accepted. 


\section{Effect of Company Size on Profitability}

The results of testing the first hypothesis are obtained that company size has no effect on profitability. The size of the company can be seen from the total assets owned by the company. The greater the size of the company, the greater the company's assets. The size of the company has no effect on profitability, this is due to the addition of assets the addition of assets that cannot be matched by the company's ability to manage its assets optimally in generating profitability.

The results of this study are consistent with the research of Prasanjaya \& Ramantha (2013), Azlina (2009), and Putra \& Badjra's (2015) research.

\section{The Effect of Net Working Capital on Profitability}

The second hypothesis testing results obtained that net working capital has a positive but not significant effect on profitability, meaning that the greater the net working capital, the lower the profitability of the company. Working capital (net working capital ) required by each company to fund its operations, so that the net working capital can directly affect the level of profitability obtained by the company. However, if the working capital available in a company is excessive compared to its needs, the company will lose the opportunity to make a profit and this will reduce the company's profitability because cash is only stored without being used productively .

The results of this study are consistent with research conducted by Kusumo \& Darmawan (2018), Octaviany \& Syahputra (2015), and research by Chotimah and Susilowibowo (2014).

\section{Effect of Profitability on Cash Holding}

The third hypothesis testing results obtained that profitability has a positive and significant effect on cash holding, meaning that the greater the profitability, the greater the company's cash holding . Profitability is a ratio to measure a company's ability to generate profits, companies with profitability high will maintain a high level of liquidity as well, or in other words, companies with high profitability levels have the opportunity to make profits are obtained as additional cash holding company.

The results of this study are consistent with research conducted by Simanjuntak \& Wahyudi (2017), Ogundipe et.al (2012), and the study of Hapsari (2015).

\section{Effect of Company Size on Cash Holding}

The fourth hypothesis results found that company size has a positive and significant effect on cash holding, meaning that the larger the size of the company, the greater the company's cash holding. The larger the size of the company, the greater the assets of the company, the size of the company will affect the size of the operating cash flow obtained by the company. Large size companies are considered capable of hoarding cash because the company has been able to achieve success in the past. So that the larger the size of a company, the greater the amount of cash 
holding companies that can be used as reserves when unexpected things happen in the future and to finance the company's investment.

The results of this study are consistent with research by Liadi \& Suryanawa (2018), Syafrizaliadhi \& Arfianto (201 4), and Ali, et al (2015).

\section{The Effect of Net Working Capital on Cash Holding}

The fifth hypothesis testing results obtained that net working capital has a positive and significant effect on cash holding, meaning that the greater the net working capital , the greater the company's cash holding . Cash is part of net working capital so that when cash rises, net working capital will also increase. In certain conditions, current assets except cash cannot be a substitute for cash at any time, for example during a crisis. Therefore, company managers usually create cash reserves to maintain company liquidity.

The results of this study are in accordance with the research of Hapsari (20 15 ), Wiradharma et , al (20 17), and Sapitri (2016).

\section{Effect of Company Size on Cash Holding through Profitability}

Based on the sixth hypothesis testing states that profitability is not able to mediate the effect of company size on cash holding. The size of the company's assets cannot increase the profitability of the company because the company is not able to manage its assets optimally so that this will have an impact on decreasing the company's cash holding .

\section{The Effect of Net Working Capital on Cash Holding Profitability}

Based on testing the seventh hypothesis states that profitability is not able to mediate the effect of net working capital on cash holding. The large net working capital of a company can increase the profitability that a company will produce due to its abundant resources. With high profitability, the company has the opportunity to make profits obtained in addition to the company's cash holding .

\section{CONCLUSION}

Based on the results of the analysis and discussion, the conclusions of this study are:

1. The size of the company has no effect on profitability

2. The greater the net working capital, the lower the profitability of the company

3. The greater the profitability, the greater the cash holding

4. The larger the size of the company, the greater the cash holding

5. The greater the net working capital the greater the cash holding

6. Profitability is not able to mediate the effect of company size on cash holding

7. Profitability is able to mediate the effect of net working capital on cash holding 


\section{REFERENCES}

Afif, Saleh. Analysis of Factors Affecting Cash Holding Policy. 2016

Ali, Shaukat., Mishkat Ullah., \& Nazir Ullah. Determinants Of Corporate Cash Holdings. 2015

Ardiana, Erna \& M Chabachib. Analysis of the Effect of Capital Structure, Company Size and Liquidity on Firm Value with Profitability as Intervening Variables (Study of Consumer Goods Companies Registered in BEI in 20122016). Diponegoro Journal of Management. 7 (2), 2018.

Azlina, Nur. Effect of Growth Rate of Working Capital, Capital Structure and Firm Scale on Profitability. Journal Pekbis. 1 (2), 2009.

Bambang, Riyanto. Fundamentals of Company Spending. Yogyakarta: Bpfe, 1998.

Chotimah, Chusnul \& Joni Susilowibowo. Effect of Capital Structure, Working Capital, and Sales Growth on Profitability. Journal of Management Science. 2 (2), 2014

Gill Amarjit \& Shah Charul. Determinant Of Corporate Cash Holdings: Evidence from Canada. International Journal of Economics and Finance. 4 (1), 2012.

Hapsari, Ajeng A. Factors That Affect the Number of Cash Holdings in the Company. Indonesian Business Management Journal. 3 (1), October 1, 2015

Jamil, Sulaman., Amna Anwar., Naila Afzaal., Adnan Tariq., \& Mohsin Asif. Determinants Of Corporate Cash Holdings: Empirical Analysis Of Pakistani Firms. Iosr Journal of Economics and Finance (Iosr-Jef). 7 (3), 2016

Jinkar, Rabecca Theresia. Analysis of Determinants of Indonesian Manufacturing Companies Cash Holding Policy.Journal of the Faculty of Economics, University of Indonesia, 2013 .

Kusumo, C Yuwono \& Ari Darmawan. The Effect of Working Capital Turnover, Company Size, and Diversification on Profitability (Study of Food and Beverage Companies Registered in BEI 2013-1016). Journal of Business Administration (Jab). 57 (1), 2018.

Liadi, Cicilia Citra, \& I Ketut S. Effect of Company Size, Net Working Capital, Cash Flow, and Cash Conversion Cycle on Cash Holding . E-Journal of Udayana University Accounting . 16 (2), 2018.

Liestyasih Luh P. E \& Luh P Wiagustini. Effect of Firm Size and Growth Opportunity on Cash Holdings and Firm Value. E-Journal of Economics and Business, Udayana University. 6 (10), 2017.

Octaviany, Ayu. Syamsul H., \& Miftahudin. Effect of Company Size and Leverage on Firm Value with Profitability as Intervening Variables. Journal of Management and Entrepreneurship Research. 3 (1), 2019.

Octaviany, Ellyn \& Defi Jumadil Syahputra. The Effect of Working Capital Efficiency and Liquidity on Profitability in Pharmaceutical Sub-Sector Companies Registered in BEI. Scientific Journal of the Faculty of Economics Accounting. 1 (2), 2015 .

Ogundipe, Lawrecia Olatunde, Sunday E. Ogundipe, And Samuel Kehide Ajao. Cash Holding And Firm Characteristics: Evidence from the Nigerian Emerging Market. Journal of Business, Economics and Finance. 1 (2), 2012. 
Parmita, Patricia Dhiana. The Effect of Working Capital Turnover, Receivable Turnover And Firm Size On Profitability Moderated Liquidity In Pt Lk Semarang Period 2013-2016. Management Journal 2017

Prasanjaya, AA Yogi., \& I Wayan Ramantha. Analysis of the Influence of Car, Bopo, Ldr Ratio and Company Size on the Profitability of Banks Registered in BEI. EJournal of Udayana University Accounting. 4 (1), 2013.

Putra, AA Wela Yulia \& Ida Bagus Badjra. Effect of Leverage, Sales Growth and Firm Size on Profitability. Eud Management E-Journal. 4 (7), 2015.

Rahmawati, Zahrotul A. Factors Affecting Cash Holding Decisions in Food and Beverages Companies Listed on the Indonesia Stock Exchange, 2013.

Sapitri, Puput. Effect of Net Working Capital, Board Size, Growth Opportunity And Cash Conversion Cycle Of Cash Holdings. 2015

Silean, Reni \& Prasetiono. Analysis of Factors Affecting Cash Holding Levels at Commercial Banks Listed on the Indonesia Stock Exchange in 20112015. Diponegoro Journal of Management. 6 (3), 2017.

Simanjuntak, Saul F. \& A. Sri Wahyudi. Factors That Affect Company Cash Holding . Journal of Business and Accounting. 19 (1), 2017.

Suhartono, Agus. Financial Management Applications and Theory. Yogyakarta: Bpfe, 2016 .

Supriadi, Yoyon., \& Ratih Puspitasari. The Effect of Working Capital on Company Sales and Profitability at Pt Indocement Tunggal Prakarsa Tbk, 2011

Syafrizaliadhi, Adhitya D. \& Erman D. Arfianto. Factors That Affect Cash Holding Behavior in Large Companies and Small Companies. Diponegoro Journal of Management. 3 (3), 2014

Wiradharma IG, Pusparini H, \& Karim N K. Analysis Of Growth Opportunity, Net Working Capital, Leverage, And Cash Conversion Cycle Influence On Cash Holdings Of Companies From Food And Drink Sub Sector In Indonesia Stock Excange. Journal of Accounting Research . 16 (1), 2017 